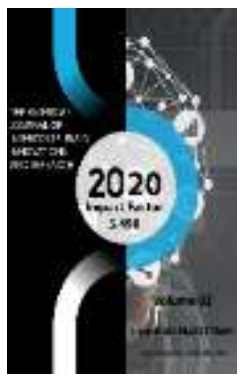

Journal Website: http://usajournalshub.c om/index,php/tajiir

Copyright: Original content from this work may be used under the terms of the creative commons attributes 4.0 licence.

\section{The Desert Tourism And Opportunities For Its Development (On The Example Of Bukhara Region)}

\author{
Mavlonov Ahmadjon Muhamadovich \\ Lecturers Of Bukhara State University, Uzbekistan \\ Mirzoeva Istat Elmurodovna \\ Lecturers Of Bukhara State University, Uzbekistan \\ Kalandarova Dilobar Davronovna \\ Lecturers Of Bukhara State University, Uzbekistan
}

\title{
ABSTRACT
}

The territory of Uzbekistan consists of temperate and subtropical desert zones. 88.6\% of Bukhara region is desert. Ancient roads in the desert part of the region (Bukhara - Karshi, Bukhara - Khorezm, etc.), water bodies (Amu-Bukhara canal, abandoned lakes, cisterns, mineral springs and wells, etc.) and special reserves (state orders, reserves, etc.), ancient cities (Varakhsha, Poykent, Vardonze, etc.), historical monuments and shrines can serve as tourist attractions.

In this article we will discuss the desert tourism and opportunities for developing it in Bukhara region.

\section{KEYWORDS}

Tourism, desert tourism, opportunities, Bukhara region, Jayran ecological center, reserve.

\section{INTRODUCTION}

Today, tourism is one of the fastest growing industries in the world. Human interest in different countries and regions, the picturesque nature of states, the diversity of their economies and the social lifestyles of their inhabitants cause millions of people around the world to travel as tourists every year. In addition, each country has created specialized tourism networks based on its natural conditions, national mentality of its population and unique history. And natural conditions play an important role in the 
formation of the tourism industry. For example, the northern countries have more winter tourism, the Alpine countries have more mountain tourism, the coastal countries have more beach tourism, and the Sahara countries have more desert tourism. Similarly, the forest tourism, steppe and pasture tourism, river and lake tourism along major rivers and lakes have been formed in the forest zone area by regions of the world.

\section{MATERIALS AND METHODS}

Some local scientists (Z.M. Akramov, A.Abdulkasimov, I.K. Nazarov) also acknowledged that more than $70 \%$ of our country is occupied by deserts. Desert areas occupy the western and central parts of the republic, including Ustyurt, Kyzylkum, Lower Zarafshan, Karshi Desert, Mirzachul and others.

The territory of Uzbekistan consists of temperate and subtropical desert zones. The temperate deserts include the Ustyurt Plateau, the northern foothills of the Amu Darya, and the subtropical deserts include the Amudarya delta, Kyzylkum, Lower Zarafshan, and the foothills of the Kashkadarya foothills.

These natural landscapes are effectively used in various sectors of the national economy of the Republic of Uzbekistan. In particular, desert areas, which make up more than $70 \%$ of the country's territory, have great potential. Bukhara region is one of the regions in the south-west of Uzbekistan, located entirely in the desert zone. Naturally, the territory of the region is occupied by the Lower Zarafshan district and a large part of the Kyzylkum desert. The desert part of the region is widely used today in industries such as mining (mining, fuel, construction materials, etc.), animal husbandry (Karakul) and transport. However, the tourist potential of the deserts is also unique.

$88.6 \%$ of Bukhara region is desert. Ancient roads in the desert part of the region (Bukhara - Karshi, Bukhara - Khorezm, etc.), water bodies (Amu-Bukhara canal, abandoned lakes, cisterns, mineral springs and wells, etc.) and special reserves (state orders, reserves, etc.), ancient cities (Varakhsha, Poykent, Vardonze, etc.), historical monuments and shrines can serve as tourist attractions.

In addition, the issuance of a number of resolutions and decrees by the President of the country over the past 3-4 years is the basis for further development of the industry. And it requires the further development of not only domestic but also foreign tourism in the regions and the effective use of existing opportunities.

There is an opportunity to organize year-round tourism in the desert areas of Bukhara region in the state orders and reserves. For example: the Bukhara Specialized Jayran Reserve which was founded in 1977 and is located $42 \mathrm{~km}$ southeast of Bukhara near the Bukhara-Karshi highway. Initially, it was referred as the" Bukhara special care facility for the breeding of the gazelle" and its task was to investigate the problems of breeding, biology and rational use of population resources of this unique animal species. According to the recommendation of the scientists, 5145 hectare desert landscapes (erosion subsidence) between Momojurgoti and Saritosh plateaus were allocated for the establishment of the reserve. This area, where the desert and fauna are widespread, is fully compatible with the natural areas inhabited by 
the gazelle. In addition, the Amu-Bukhara Canal flows from the south of the reserve.

As a result of research conducted by scientists, the number of rare animals in the reserve area has increased. Initially, 43 gazelle were protected, but today 1,045 gazelle, 172 Turkmen kulans, 17 Przewalski's horses, 2 Hongul (Bukhara deer), 52 Bukhara mountain sheep and other species are protected.

A policy has been pursued to expand the area of the Jayran Eco-Center, which specializes in the breeding of rare species of animals. On February 2, 2009 by the decision of the Bukhara regional khokimiyat No. 809363 hectares of land were transferred to the balance of the eco-center, the area of which reached 16.5 thousand hectares. In 2011, with the sponsorship of the Shurtan Gas Chemical Complex, new sites were added to the territory of the eco-center. The territory of the ecological center "Jayran" is conditionally divided into two parts. The area of the first is 5,000 hectares, where rare animal species are bred. In the second part, with an area of 11.5 thousand hectares, there is an adaptation center. It is bred naturally for Turkmen slaves, Przewalski's horses and gazelles.

The tourist potential of the Bukhara specialized reserve "Jayran" is incomparable. In the charming desert nature, unique animals and unique landscape, you can relax, unwind, restore health and enjoy the beauty of nature. In addition, the convenient geographical location of the eco-center allows it.

Any tourist visiting the Jayran Reserve can have such opportunities:

Rest (relaxation) in the vast desert nature;
$>$ Restoring health by enjoying desert landscapes;

$>$ Knowledge of desert animals and their biology;

$>$ Familiarity with desert flora and its peculiarities;

$>$ Joining the conservation of biodiversity and nature conservation in the desert;

$>$ Achieving an increase in environmental culture through information on hunting tourism, hunting;

$>$ Organization of field trips and field (mobile) lessons for pupils and students in the nature of the desert, in natural laboratories, etc.

Based on the above, it is expedient to further develop domestic tourism in the reserve "Jayran". First of all, it is necessary to take measures to attract schoolchildren and students. And the promotion of the "Jayran" reserve in educational institutions and mahallas, roundtables aimed at improving nature conservation and environmental culture among young people give good results. Regular updating of the site of the eco-center "Jayran", the organization of online tourist routes around the reserve will also have a positive effect.

At present, the Bukhara specialized reserve "Jayran" has begun practical work to further improve tourism and the formation of tourist infrastructure. In particular, the site of the reserve has been established including the establishment of a museum in the eco-center and the construction of a hotel and a conference hall in the reserve. There is no doubt that the construction of these facilities in the near future in the reserve "Jayran" will 
develop not only domestic but also foreign tourism.

It is also possible to create tourist centers and nodes along water bodies in arid areas. And hydrographic objects play a key role in the development of arid areas. Freshwater rivers and canals play a special role in the development of desert regions. In particular, the importance of the Amu-Bukhara machine canal in the socio-economic life of Bukhara region is incomparable. At present, a total of 314.9 thousand hectares, including 275.0 thousand hectares in Bukhara region and 39.9 thousand hectares in Navoi region, are irrigated by the Amudarya River. However, the level of use of the canal in other sectors of the economy, especially for recreational purposes, is not satisfactory. On the banks of the AmuBukhara machine canal (Phases I-II) there are wooded, bushy groves that can be used for recreational purposes. In the wooded groves with a width of 8-12 meters along the water, dark poplar (type 2), willow, jiida, wicker reed, willow, ordinary reed paths were formed (Table 1).

Types of recreation of the Amu-Bukhara machine canal

\begin{tabular}{|c|c|c|c|c|}
\hline $\begin{array}{l}\text { Types of } \\
\text { recreational } \\
\text { use }\end{array}$ & $\begin{array}{l}\text { Location } \\
\text { features }\end{array}$ & $\begin{array}{l}\text { Access to } \\
\text { facilities }\end{array}$ & $\begin{array}{l}\text { Names of } \\
\text { recreational } \\
\text { areas }\end{array}$ & $\begin{array}{l}\text { Availability of } \\
\text { infrastructure }\end{array}$ \\
\hline $\begin{array}{l}\text { Swimming in a } \\
\text { boat }\end{array}$ & $\begin{array}{l}\text { The width of } \\
\text { the canal is } 10-14 \\
\mathrm{~m} \text {, the width of } \\
\text { the water level } \\
\text { is } 14-16 \mathrm{~m} \text {, the } \\
\text { depth is } 4-6 \mathrm{~m} \text {. }\end{array}$ & $\begin{array}{l}\text { Bukhara } \\
\text { Karavulbozor } \\
\text { bus route }\end{array}$ & $\begin{array}{l}\text { Gavan bridge - } \\
\text { Karavulbozor } \\
\text { bridge }\end{array}$ & $\begin{array}{l}\text { The roads to the } \\
\text { destinations are } \\
\text { paved. } \\
\text { Infrastructure is } \\
\text { not available. }\end{array}$ \\
\hline Fishing (sport) & $\begin{array}{l}\text { Amu-Bukara } \\
\text { machine } \\
\text { channel } \quad \text { (I-II } \\
\text { turns) shore } \\
\text { rocks }\end{array}$ & $\begin{array}{l}\text { Bukhara- } \\
\text { Karavulbozor } \\
\text { route bus route }\end{array}$ & $\begin{array}{l}\text { Gavan bridge } \\
\text { Karavulbozor } \\
\text { bridge }\end{array}$ & $\begin{array}{l}\text { The roads to the } \\
\text { destinations are } \\
\text { paved. } \\
\text { Infrastructure is } \\
\text { not available. }\end{array}$ \\
\hline Travel tourism & $\begin{array}{l}\text { Study of flora } \\
\text { and fauna of } \\
\text { the region }\end{array}$ & $\begin{array}{l}\text { Bukhara- } \\
\text { Karavulbozor } \\
\text { route bus route }\end{array}$ & $\begin{array}{l}\text { In the area } \\
\text { where the Jayran } \\
\text { Ecological Center } \\
\text { is located }\end{array}$ & $\begin{array}{l}\text { The roads to the } \\
\text { destinations are } \\
\text { paved. } \\
\text { Infrastructure is } \\
\text { available. }\end{array}$ \\
\hline
\end{tabular}


The American Journal of Interdisciplinary Innovations and Research (ISSN-2642-7478)

Published: December 27, 2020 | Pages: 68-73

Doi: https://doi.org/10.37547/tajiir/Volumeo2Issue12-10

\begin{tabular}{|l|l|l|l|l|}
\hline $\begin{array}{l}\text { Restoration of } \\
\text { health }\end{array}$ & $\begin{array}{l}\text { Arranging a rest } \\
\text { on the slopes } \\
\text { around the } \\
\text { canal }\end{array}$ & $\begin{array}{l}\text { Bukhara- } \\
\text { Karavulbozor } \\
\text { route bus route }\end{array}$ & $\begin{array}{l}\text { In the area } \\
\text { where the } \\
\text { Bukhara-Karshi } \\
\text { road crosses }\end{array}$ & $\begin{array}{l}\text { The roads to the } \\
\text { destinations are } \\
\text { paved. } \\
\text { Infrastructure is } \\
\text { not available. }\end{array}$ \\
\hline
\end{tabular}

The table was compiled by the author.

As the table shows that the Amu-Bukhara machine canal can be used for recreational purposes such as boating, fishing (sports), travel tourism, rehabilitation. However, the lack of infrastructure limits the use of the canal area for recreational purposes. Therefore, in the near future it is advisable to build modern hotels (for example, near the Jayran Ecological Center) and public catering establishments.

In addition, there is an opportunity to implement daily tourist routes through the desert areas of the region. Such routes can be implemented in such ancient cities as Varakhsha, Poykent, Vardonze, as well as in the tourist centers around the Bukhara Dessert Oasis \& Spa and the Todakol Reservoir. You can also visit more than 10 "tourist neighborhoods" and "tourist villages" in the region, where you can enjoy the conditions created and the rich national traditions, customs and crafts of our people.

In short, the desert regions, especially Bukhara region, have great tourist potential. In particular, the ancient roads in the desert part of the region (Bukhara - Karshi, Bukhara Khorezm, etc.), water bodies (Amu-Bukhara machine canal, abandoned lakes, cisterns, mineral springs and wells, etc.) and special protected areas (government orders, nurseries, etc.), the use of ancient cities (Varakhsha, Poykent, Vardonze, etc.) as tourist facilities has great prospects. Currently, some of them are used in tourism, especially domestic tourism. However, in the future, by improving the tourist infrastructure, there is an opportunity to use these facilities as objects of international tourism. And it is necessary to group these facilities in terms of tourism and to increase the number of media outlets informing tourists about these tourist facilities, as well as to develop advertising and propaganda work. In addition, further improvement of modern tourist infrastructure around tourist facilities will serve to increase the flow of tourists.

\section{REFERENCES}

1. Mavlonov A.M. Desert urbanization. Bukhara. Durdona Publishing House. 2015. -176 p.

2. Mavlonov A.M., Jalilova Ch. Some aspects of the use of recreational resources of Bukhara region. Issues of mitigating the negative effects of adverse environmental factors in the Aral Sea region. Materials of scientific-practical conference of the republic. -Bukhara, 2020.- p. 28-30. 
3. Toshov H.R., Mavlonov A.M. Amu-Bukhara car canal - as a recreational resource. Geographical problems and opportunities for the development of tourism and recreation in Uzbekistan. Proceedings of the international scientific-practical conference. -Chirchik, 2019.- p. 217-219.

4. Gulshan Halimova, Fazliddin Khikmatov, Sherzod Zaitov, Anvar Nematov. Assesment of Local Water Resource in Kuljuktov Mountain System. Test Engineerihg \& Management. Volume 83.9 April 2020, Pages 8665-8668March - April 2020. ISSN: 0193-4120 